International Journal of Engineering \& Technology, $7(3.29)(2018) 259-262$
SPC
Snternational Journal of Engineering \& Technology
Website: $w w w . s c i e n c e p u b c o . c o m / i n d e x . p h p / I J E T$
Research paper

\title{
Analysis of time overruns in roads and highways sector in India using AHP ranking technique
}

\author{
Prof. Siddesh K. Pai ${ }^{1 *}$, Avinash Kumar Singh ${ }^{2}$, Dr. Ankur Mittal ${ }^{3}$, Dr. Neeraj Anand ${ }^{3}$ \\ ${ }^{1}$ National Institute of Construction Management and Research (NICMAR) \& Research scholar, UPES, Dehradun \\ ${ }^{2}$ Project coordinator - Dilip Buildcon Ltd, MP - India \\ ${ }^{3}$ University of Petroleum and Energy Studies (UPES), Dehradun - India \\ *Corresponding author E-mail: talk2sidd@gmail.com
}

\begin{abstract}
In today's scenario there will be a competition exists among various construction firm, so the risk management come into picture to assess the various risk related to project. Assigning the right severity factor as per the possibility of occurrence will impart the success of organization as well as success will impart the growth of nation with increase in G.D.P. In construction of road the assessment of right severity factor, will be considered as strength to lower down the delay of time over run. Tremendous amount of effort are applied in quantitative and qualitative manner for assessment of risk severity factor. However, many criteria for risk severity factor enable the decision making methods will smoothen the process of arriving at a solution and enable decision makers to make the right decisions. Decision-making problems need systematic approach to appraise the various alternatives using quantitative and non quantitative factors. Standard methods for solving problems will lack considerations of non-quantitative factors, where numeric values are difficult to assign. Different techniques like, Analytic Hierarchy Process (AHP), Fuzzy set theory Making and Multi Criteria Decision are being used in risk severity factor. These techniques consider factors with concrete values or vague values. This research will provide solution to a risk severity factor for budget allocation problem, for allocating funds to competing and deserving organizations by using ranking analysis technique. Fuzzy set theory and AHP is used to calculate the Weights .Fuzzy set considers subjective values like preferred, strongly preferred etc. and Analytic Hierarchy Process (AHP) technique evaluates relative importance of factors by making pair wise comparison matrix. The evaluation technique will facilitate in ranking of various severity factors according to their possibility of occurrence after assigning weights to decision making factor.
\end{abstract}

Keywords: AHP (Analytical Hierarchy Process); MCDM (Multi Criteria Decision Making Approach); Ranking and Severity Analysis.

\section{Introduction}

India is developing country and transportation forms the cornerstone of the Indian Economy. Other modes of transportation may be used for long range but for door to door operation the transportation mode is one which majority of population use. Road construction enhances the integral part of the infrastructure and also responsible for nearby vicinity development [1].

Construction project, from inception to closure, encounter numerous risk that may affect the completion time of project. These risks may relate from initiation phase of project and probability of occurrence may be throughout project life cycle. These risk are unique in nature and there occurrence may vary from project to project. Managing the risk in construction project is considered as a very crucial process in order to minimise the risk throughout project life cycle. The occurrence of risk will be enhanced in two manner probability or likelihood of occurrence and there consequences or impacts if it does. Management of risk is an integral part of achievement of good business and successfully completion of project which directly affects the cost. Risk management provides a structured way of dealing and forecasting with uncertainty. The fuzzy logic method is often used in the analysis of such data. The Fuzzy AHP method, which is one of the multi-criteria decision making methods was used to positioning the rank to various associated risk in National Highway Road Project [2].
The occurrence of risk in the various phases of project termed as:

- Pre-feasibility phase.

- Feasibility phase.

- Execution phase.

- Operation phase.

These are the basics criteria for emphasising the risk, integration of risk will be more so that it must be analysed and solved in individual phase of project. The road and highway are the very complex project minor error shall be responsible for major loss [3].

As per the guideline preliminary phase in which the over-view of project should be seen it is in the form of various availability of various facility nearby the area of the site, various source of material and availability of natural resources. If it allows then the further study shall be carried out in detail manner and accordingly the assessment of risk shall be a carried out. This is followed by the each phase of project [4].

\section{Need for study}

India is developing country increment in the stretch length of road network is worked out on wider basis and assessment of risks become very important factor to minimise the risk as well as time over run. 


\section{Objective}

To conduct micro level analysis of risk prone phase of road projects with the help of mathematical tool as well as expertise view.

\section{Literature review}

As per the observation and analysis of this paper Risk planning in construction of highway project. It will emphasise the different phase of project life cycle for the implementation of effective risk management planning in construction of highway project. Study on Risk planning on construction of highway project [5].

As per the observation and analysis of this paper Risk management for national highway project .The nature of work will be very complex in road sector while utilizing these technique one can assess the severity of risk in whole project life cycle and accordingly to mitigate the risk impact one can work with help of ranking of risk. Study of Risk management for national highway project [6] As per the observation and analysis of this paper risk management in the infrastructure project in India the main Moto of risk assessment is to minimize the shortfall of risk to achieve the target in terms of Time ,Cost and quality . Risk policy will be introduced to mitigate the risk throughout project life cycle. Study on Risk Management in infrastructure project in India [7].

\section{Methodology}

a) FUZZY-AHP Method

The analytic hierarchy process (AHP) is a systematic technique for the purpose of analyzing and organizing complex decision making technique based on data evaluation in terms severity factor and psychology. The scientist who developed this method is Thomas Saaty in the year 1970s and the method has been continuously studied and refined since then.[8] It will not prescribing the "correct" decision but probably it will be one of the best method applying to the goal and understanding of the problem[5]. It provides a comprehensive and rational framework for structuring a decision making problem, for representing and quantifying its elements, understanding relations of those elements to various goals, and for assessing alternative solutions.

To solve the decision problems with AHP, the following are some steps which are mentioned below [9].

STEP 1: Determination of geometric mean of the data collected.

STEP 2: A comparison matrix between factors is formed, which is an nxn dimensional square matrix. The matrix components on the diagonal of this matrix take value 1 .

STEP 3: Determine the weight of each factor.

After collection of the expert views \& compiling data collected, next is to determine the weight of each factor. Weights are calculated by applying AHP method technique. First revise comparison matrix, compare the importance of one alternative than other.

STEP 4: Percentage distribution for importance of the criteria is determined

Comparison matrix determines importance levels of factors to each other within a certain logic framework. Calculating the weight of these factors in total, in other words to determine the percentage importance distribution.

STEP 5: Calculation of most probable value.

As per the data collected in terms of various ranking assign to the for the different types of questionnaire we will assign the ranking with the help of AHP-FUZZY

Table 1:

\begin{tabular}{|c|c|c|}
\hline $\begin{array}{l}\text { Factor } \\
\text { ID(A) }\end{array}$ & VARIOUS SEVERITY FACTOR & $\begin{array}{l}\text { GEOMETRIC } \\
\text { MEAN C }\end{array}$ \\
\hline 1 & Law and order situation/Security threats/Local Agitations & 3.567958 \\
\hline 2 & Land acquisition delays & 3.375707 \\
\hline 3 & Change in government policies affecting project & 3.902599 \\
\hline 4 & $\begin{array}{l}\text { Delay in Center/State government document } \\
\text { clearance process }\end{array}$ & 2.502215 \\
\hline 5 & Change in political power at State/ Center & 2.864157 \\
\hline 6 & Excessive bureaucracy with organization & 1.960781 \\
\hline 7 & Favoritism in consultant/contractor selection & 1.742024 \\
\hline 8 & Price fluctuations due to Inflation & 4.043857 \\
\hline 9 & Global/National Economic crises & 3.518009 \\
\hline 10 & Lack of project funding & 3.192508 \\
\hline 11 & Improper project feasibility study & 2.651692 \\
\hline 12 & Project complexity (Project type, project scale,etc) & 3.799014 \\
\hline 13 & Change/Transfer of project personnel during project execution & 2.41744 \\
\hline 14 & Force majeure activities/unforeseen circumstances & 2.531694 \\
\hline 15 & Unrealistic contract/project duration & 1.716488 \\
\hline 16 & Haste in preparing project design & 2.131215 \\
\hline 17 & Delay in selection of PMC/contractors/suppliers & 4.165288 \\
\hline 18 & Issues in client procured materials & 1.610862 \\
\hline 19 & Ignorance in penalizing for delay & 1.84455 \\
\hline 20 & Wrong Type of project award (Turnkey,BOT,etc) & 1.67633 \\
\hline 21 & Lackadaisical attitude towards work completion & 1.90676 \\
\hline 22 & Coordination with foreign consultants & 2.058957 \\
\hline 23 & Environmental concerns and restrictions & 4.094911 \\
\hline 24 & Geological problems on site & 3.492622 \\
\hline 25 & Poor site access & 1.820024 \\
\hline 26 & Lack in follow-up procedure with government to start project & 2.152002 \\
\hline 27 & Improper conflict resolution process adopted & 2.938057 \\
\hline 28 & Severe weather conditions at site & 2.800151 \\
\hline 29 & Ambiguous project requirements & 2.190524 \\
\hline 30 & Improper contractor/Consultant selection & 2.728591 \\
\hline 31 & Delay in progress payments & 3.05378 \\
\hline 32 & Frequent project scope/Design changes & 3.301318 \\
\hline 33 & Slow decision making process & 3.728198 \\
\hline 34 & Lack of competent/expert project domain people & 2.16008 \\
\hline 35 & Delay in finalization of rates for extra items & 3.016275 \\
\hline
\end{tabular}

After collection of the expert view for these all questionnaire followed by compiling of data collection, next is to determine the 
weights for each factor. So that pair wise comparison matrix is formulated. With the help of this matrix we are in a position to compare the important of one matrix over other [10].

b) Sample calculation

$\mathrm{C} 1 / \mathrm{C} 1=3.567958 / 3.56958$ (This will be shown in horizontal order in a matrix). $=1$

Again $\mathrm{C} 1 / \mathrm{C} 2=3.567958 / 3.375707$ (This the reverse order). $=1.05695$.

With the help AHP method we are in a position to get the various severity factor for these data .To understand the below matrix, let us take the case of another matrix
Consider

$\mathrm{C} 34 / \mathrm{c} 34=2.16008 / 2.16008=1$

$\mathrm{C} 34 / \mathrm{c} 35=2.16008 / 3.016275=0.71614$.

Basically comparison is made between both each of factors to relative one from $\mathrm{C} 1$ to $\mathrm{C} 35$. The diagonal element have value one.

Evaluation of weight age:

c) Determination of matrix.

Table 2:

\begin{tabular}{|c|c|c|c|}
\hline \multicolumn{4}{|c|}{ FINAL RESULT OF SEVERITY FACTOR } \\
\hline NO. & Severity factor of column 1 & Final result of severity factor & RANK ODER \\
\hline $\mathrm{C} 1$ & 1 & 0.03691374 & 7 \\
\hline $\mathrm{C} 2$ & 0.946117359 & 0.0349 & 10 \\
\hline $\mathrm{C} 3$ & 1.093790622 & 0.0404 & 4 \\
\hline $\mathrm{C} 4$ & 0.701301697 & 0.0259 & 21 \\
\hline C5 & 0.802744035 & 0.0296 & 16 \\
\hline C6 & 0.549552713 & 0.0203 & 28 \\
\hline $\mathrm{C} 7$ & 0.488241173 & 0.0180 & 32 \\
\hline $\mathrm{C} 8$ & 1.133381335 & 0.0418 & 3 \\
\hline C9 & 0.986000676 & 0.0364 & 8 \\
\hline $\mathrm{C} 10$ & 0.894771743 & 0.0330 & 12 \\
\hline C11 & 0.743195968 & 0.0274 & 19 \\
\hline $\mathrm{C} 12$ & 1.06475861 & 0.0393 & 5 \\
\hline C13 & 0.677541608 & 0.0250 & 22 \\
\hline $\mathrm{C} 14$ & 0.709563846 & 0.0262 & 20 \\
\hline C15 & 0.481084138 & 0.0178 & 33 \\
\hline C16 & 0.597320652 & 0.0220 & 26 \\
\hline $\mathrm{C} 17$ & 1.167415087 & 0.0431 & 1 \\
\hline C18 & 0.45148009 & 0.0167 & 35 \\
\hline C19 & 0.516976377 & 0.0191 & 30 \\
\hline $\mathrm{C} 20$ & 0.469828961 & 0.0173 & 34 \\
\hline $\mathrm{C} 21$ & 0.53441212 & 0.0197 & 29 \\
\hline $\mathrm{C} 22$ & 0.577068732 & 0.0213 & 27 \\
\hline $\mathrm{C} 23$ & 1.14769036 & 0.0424 & 2 \\
\hline C24 & 0.978885402 & 0.0361 & 9 \\
\hline $\mathrm{C} 25$ & 0.510102417 & 0.0188 & 31 \\
\hline C26 & 0.603146674 & 0.0223 & 25 \\
\hline $\mathrm{C} 27$ & 0.823456162 & 0.0304 & 15 \\
\hline $\mathrm{C} 28$ & 0.784804922 & 0.0290 & 17 \\
\hline C29 & 0.613943326 & 0.0227 & 23 \\
\hline C30 & 0.764748632 & 0.0282 & 18 \\
\hline C31 & 0.85589012 & 0.0316 & 13 \\
\hline C32 & 0.925268179 & 0.0342 & 11 \\
\hline $\mathrm{C} 33$ & 1.044910843 & 0.0386 & 6 \\
\hline C 34 & 0.605410714 & 0.0223 & 24 \\
\hline C35 & 0.845378505 & 0.0312 & 14 \\
\hline
\end{tabular}

d) Ranking of Factor

Table 3:

\begin{tabular}{lllll}
\hline Sr. No & Ranking According To Order & severity factor & Rank & Severity Factor \\
\hline C1 & Delay in selection of PMC/contractors/suppliers & 0.0431 & 1 & Very High \\
C2 & Environmental concerns and restrictions & 0.0424 & 2 & Very High \\
C3 & Price fluctuations due to Inflation & 0.0418 & 3 & Very High \\
C4 & Change in government policies affecting project & 0.0404 & 4 & Very High \\
C5 & Project complexity (Project type, project scale, etc) & 0.0393 & High \\
C6 & Slow decision making process & 0.0386 & High \\
C7 & Law and order situation/Security threats/Local Agitations & 0.0369 & 7 & High \\
C8 & Global/National Economic crises & 0.0364 & 8 & High \\
C9 & Geological problems on site & 0.0361 & 9 & High \\
C10 & Land acquisition delays & 0.0349 & 10 & High \\
C11 & Frequent project scope/Design changes & 0.0342 & High \\
C12 & Lack of project funding & 0.0330 & 11 & High \\
C13 & Delay in progress payments & 0.0316 & 12 & High \\
C14 & Delay in finalization of rates for extra items & 0.0312 & 13 & High \\
C15 & Improper conflict resolution process adopted & 0.0304 & 15 & High \\
C16 & Change in political power at State/ Center & 0.0296 & 16 & High \\
C17 & Severe weather conditions at site & 0.0290 & 17 & Moderate \\
C18 & Improper contractor/Consultant selection & 0.0282 & 18 & Moderate \\
C19 & Improper project feasibility study & 0.0274 & 19 & Moderate \\
C20 & Force majeure activities/unforeseen circumstances & 0.0262 & 20 & Moderate \\
C21 & Delay in Center/State government document clearance process & 0.0259 & 21 & Moderate \\
C22 & Change/Transfer of project personnel during project execution & 0.0250 & Moderate \\
C23 & Ambiguous project requirements & 0.0227 & 22 & Moderate \\
\hline
\end{tabular}




\begin{tabular}{|c|c|c|c|c|}
\hline $\mathrm{C} 24$ & Lack of competent/expert project domain people & 0.0223 & 24 & Moderate \\
\hline C25 & Lack in follow-up procedure with government to start project & 0.0223 & 25 & Low \\
\hline $\mathrm{C} 26$ & Haste in preparing project design & 0.0220 & 26 & Low \\
\hline $\mathrm{C} 27$ & Coordination with foreign consultants & 0.0213 & 27 & Low \\
\hline $\mathrm{C} 28$ & Excessive bureaucracy with organization & 0.0203 & 28 & Low \\
\hline $\mathrm{C} 29$ & Lackadaisical attitude towards work completion & 0.0197 & 29 & Very Low \\
\hline $\mathrm{C} 30$ & Ignorance in penalizing for delay & 0.0191 & 30 & Very Low \\
\hline C31 & Poor site access & 0.0188 & 31 & Very Low \\
\hline $\mathrm{C} 32$ & Favoritism in consultant/contractor selection & 0.0180 & 32 & Very Low \\
\hline $\mathrm{C} 33$ & Unrealistic contract/project duration & 0.0178 & 33 & Very Low \\
\hline C34 & Wrong Type of project award ( Turnkey,BOT,etc) & 0.0173 & 34 & Very Low \\
\hline $\mathrm{C} 35$ & Issues in client procured materials & 0.0167 & 35 & Very Low \\
\hline
\end{tabular}

\section{Conclusion}

As per the data available based on expertise view as well as analysis of data with help of AHP technique we are in position to assess the various phase of risk cover throughout life cycle of project if we take into consideration as per the value of factor ID $\mathrm{C} 1$ has been assigned as very high risk categories till factor $\mathrm{C} 4$. These are the major categories of risk which cause delay in highway sector for initiation of project. Similarly if take into consideration the second most effective factor which is termed as C5 shall be also seen on micro level because assessment of risk is dynamic in nature we don't know what is coming next occurrence because as per the stretch length should increase accordingly the monitoring of risk prone area shall be taken into consideration in advance so it will not going to affect the schedule time for achievement of milestone on time. Once again our Moto to priorities this risk factor is to client or employer should look directly and very high risk prone area should be taken into consideration to save the time and cost effectively.

\section{References}

[1] Dziadosza, A. and Rejmentb, M. (2015). Risk analysis in construction project - chosen methods. Procedia Engineering, pp. 258 - 265.

[2] Dziadosza, A., Tomczykb, A. and Kaplińskic, O. (2015). Financial risk estimation in construction contracts. Procedia Engineering, 122, pp. $120-128$.

[3] Kumar, R., Sheikh, A. and. Asadi, S. (2017). A Systematic Approach for Evaluation of Risk Management in Road Construction Projects A Model Study. International Journal of Civil Engineering and Technology (IJCIET), 8(3), pp.888-902.

[4] kumar, V., Raghunath, P. and Suguna, K. (2015). Critical Factors Influencing to Management Risk in Construction Projects. ISSN (e): $2319-1813,4(1)$, pp.2319 - 1805 .

[5] M.B., K. and S.D., D. (2015). Study of risk management for National Highway Project. International Research Journal of Engineering and Technology (IRJET), 02(03), pp.2146-2152.

[6] Patha, E. and Pimplikar, P. (2013). Risk Assessment of BOT Road Projects. IOSR Journal of Mechanical and Civil Engineering (IOSRJMCE), 05(03), pp.40-59.

[7] Perera, B., Dhanasinghe, I. and Rameezdeen, R. (2010). Risk management in road construction: The case of Sri Lanka. International Journal of Strategic Property Management, 13(2), pp.87-102.

[8] S. Pawar*, C., S. Jain, S. and R. Patil, J. (2015). Risk Managemen in Infrastructure Projects in India. International Journal of Innovative Research in Advanced Engineering (IJIRAE), 2(4), pp.172-176.

[9] Vishambar1, A., Kaustubh, S., Kartik, P. and Salunkhe, A. (2016) Risk Planning in Construction of Highway Project: Case Study. International Journal of Latest Research in Engineering and Technology (IJLRET), 2(3), pp.57-63.

[10] Vishwakarma, A., Thakur, A., Singh, S. and Salunkhe, A. (2016). Risk Assessment in Construction of Highway Project. International Journal of Engineering Research \& Technology (IJERT), 05(02), pp.637-640 